\title{
Unusual case of stable dense deposit disease over 20 years
}

\author{
Satyanarayana R Vaidya*1, Chandana R Bhavanam², Ananda R Gurram³ \\ ${ }^{1}$ Department of Internal Medicine, Cape Fear Valley Medical Center, Fayetteville, NC, USA \\ ${ }^{2}$ American International Medical University, Gros Islet, Saint Lucia \\ ${ }^{3}$ Department of Nephrology, Cape Fear Valley Medical Center, Fayetteville, NC, USA
}

Received: April 21, 2016

DOI: $10.5430 /$ crim.v3n3p57
Accepted: June 14, 2016

Online Published: June 30, 2016

URL: http://dx.doi.org/10.5430/crim.v3n3p57

\begin{abstract}
Dense deposit disease (DDD) is a prototypical form of C3 Glomerulopathy that affects both children and adults at a rate of 2 to 3 people per million. It often progresses to ESRD and recurs after Renal Transplantation. DDD presentation for 10 years or more is known to progress to ESRD in half of patients. We report a rare case of DDD which has been in clinical and histological remission for 14 years after treatment with Glucocorticoid therapy.
\end{abstract}

Key Words: Dense deposit disease, C3 Glomerulopathy, Membranoproliferative Glomerulonephritis type 2, Immunofluorescence, End stage renal disease

\section{INTRODUCTION}

C3 glomerulopathy is a recently incorporated pathological entity and by definition is a glomerular pathology characterized by $\mathrm{C} 3$ accumulation with absent or scant immunoglobulin deposition. It incorporated the incorporates variants. Dense deposit disease (DDD) which is defined when characteristic highly electron dense deposits are visible on electron microscopy in addition to above pathology and $\mathrm{C} 3$ glomerulonephritis, term coined when the characteristic deposits are absent. It also includes genetic entities of Familial DDD with $\mathrm{C} 3$ gene mutation and Familial $\mathrm{C} 3$ glomerulonephritis with complement factor $\mathrm{H}$ related protein gene mutation.

Any renal biopsy which classifies lesion as $\mathrm{C} 3$ glomerulopathy should prompt an investigation of complement pathway. The differential diagnoses that need to be considered while evaluation are Post infectious glomerulonephritis (PIGN), fibrillary glomerulonephritis, Immunoglobulin A
(IgA) nephropathy and Vasculitis.

The existence of licensed complement inhibitor Eculizumab and many other complement inhibitors in clinical development makes it therapeutically relevant to identify patients who can benefit from anti complement therapeutic approach. As $\mathrm{C} 3$ glomerulopathies are alternate complement pathway diseases, is Anti complement therapy the only therapeutic option? or can some patients achieve remission with standard anti-cellular immunosuppressive therapy? as in our patient who achieved remission with steroid therapy alone. This question needs to be answered by future therapeutic trials.

\section{Case presentation}

A 37-year-old Caucasian female presents for evaluation of proteinuria. She was referred by her primary care physician. She denied any hematuria, leg edema, shortness of breath, recent upper respiratory infection, skin rash, diarrhea, over

*Correspondence: Satyanarayana R Vaidya, MD; Email: drsrvaidya@ gmail.com; Address: 6860 Surrey road, Fayetteville, NC 28306, USA. 
the counter use of NSAIDS, renal stone disease. Past medical history included membrano proliferative glomerulonephritis type 2 diagnosed at the age of 14 after she presented with hematuria and proteinuria.

Table 1. Laboratory data

\begin{tabular}{|c|c|c|c|}
\hline Variables & Normal Range & Result & Unit \\
\hline \multicolumn{4}{|l|}{ Complete blood count } \\
\hline Hemoglobin & $12-16$ & 13.1 & $\mathrm{~g} / \mathrm{dl}$ \\
\hline Hematocrit & $35-47$ & 38.3 & $\%$ \\
\hline White blood cell & $4.5-11$ & 6.6 & $\mathrm{k} / \mu \mathrm{l}$ \\
\hline Platelet count & $150-440$ & 254 & $\mathrm{k} / \mu \mathrm{l}$ \\
\hline \multicolumn{4}{|l|}{ Chemistry } \\
\hline Sodium & $135-145$ & 140 & meq/L \\
\hline Potassium & $3.5-5.0$ & 4.1 & $\mathrm{meq} / \mathrm{L}$ \\
\hline Chloride & $99-109$ & 101 & $\mathrm{meq} / \mathrm{L}$ \\
\hline Bicarbonate & $22-33$ & 23 & $\mathrm{meq} / \mathrm{L}$ \\
\hline Blood urea nitrogen & $6-20$ & 9 & mg/dl \\
\hline Creatinine & $0.6-1.10$ & 0.7 & $\mathrm{mg} / \mathrm{dl}$ \\
\hline Glucose & 70-105 & 91 & $\mathrm{mg} / \mathrm{dl}$ \\
\hline Calcium & $8.5-10.5$ & 9.1 & $\mathrm{mg} / \mathrm{dl}$ \\
\hline Total Protein & $6.2-8.3$ & 6.8 & $\mathrm{~g} / \mathrm{dl}$ \\
\hline Albumin & $3.4-4.1$ & 3.8 & $\mathrm{~g} / \mathrm{dl}$ \\
\hline \multicolumn{4}{|l|}{ Complement } \\
\hline C3 & $90-180$ & 134 & $\mathrm{mg} / \mathrm{dl}$ \\
\hline $\mathrm{C} 4$ & $9-36$ & 31 & $\mathrm{mg} / \mathrm{dl}$ \\
\hline \multicolumn{4}{|l|}{ Autoimmune studies } \\
\hline ANA & & $<40$ & \\
\hline Anti-DNA antibody & $0-9$ & 2 & $\mathrm{IU} / \mathrm{ml}$ \\
\hline Anti GBM antibody & $0-20$ & 5 & Units \\
\hline AntiMyeloperoxidase (MPO) ab & $0-9$ & $<9$ & $\mathrm{U} / \mathrm{ml}$ \\
\hline Anti Proteinase 3 (PR3) ab & $0-3.5$ & $<3.5$ & $\mathrm{U} / \mathrm{ml}$ \\
\hline C-ANCA & $<1: 20$ & $<1: 20$ & Titer \\
\hline P-ANCA & $<1: 20$ & $<1: 20$ & Titer \\
\hline Atypical P-ANCA & $<1: 20$ & $<1: 20$ & Titer \\
\hline Hepatitis B serology & Negative & & \\
\hline Hepatitis A Ab-IgM & Negative & & \\
\hline $\begin{array}{l}\text { Hepatitis C Ab } \\
\text { Hiv } 1 \& 2\end{array}$ & $\begin{array}{l}\text { Negative } \\
\text { Negative }\end{array}$ & & \\
\hline \multicolumn{4}{|l|}{ Urinalysis } \\
\hline Protein & $2+$ & & \\
\hline $\mathrm{RBC}$ & Negative & & \\
\hline Leukocyte esterase & Negative & & \\
\hline WBC & Negative & & \\
\hline Nitrite & Negative & & \\
\hline Urine culture & No growth & & \\
\hline Urine eosinophil & Negative & & \\
\hline
\end{tabular}

She had a renal biopsy in 1995, light microscopy showed extensive glomerular hyper cellularity and thickening of capillary basement membranes. Electron micrographs of that biopsy were unavailable but reportedly showed capillary loops widely replaced by typical dense deposits. Immunofluorescence staining showed minimal C3 staining. Serum C3 level was $154 \mathrm{mg} / \mathrm{dl}$, C4 was $32 \mathrm{mg} / \mathrm{dl}$. She was initially started on $1 \mathrm{mg} / \mathrm{kg}$ of prednisone (at the age of 14) and then slowly tapered to a dose of $10 \mathrm{mg}$ orally once daily over a period of 4 months.

She was then continued on the same dose for a prolonged period of time. She has been in remission since 2002 with creatinine stable at 0.7 . She had uneventful pregnancies in 1998 and 2002. She was started on ACE inhibitors in 2003. Family history was not significant for any renal disease in first degree relatives. Review of systems was significant for mild generalized weakness. Physical examination was unremarkable. Lab data showed she had a protein creatinine ratio of $181.5 \mathrm{mg} / \mathrm{g}$ and 24-hour quantification of proteinuria was $590.2 \mathrm{mg}$.

Full laboratory data is shown in Tables 1, 2. Urine microscopy showed no RBC casts, WBC casts, transitional, squamous epithelial cells or fungal elements. Renal biopsies in 2016 showed dense deposits in glomerular basement membrane on electron microscopy (see Figure 1). The Light microscopy shows mesangial proliferation only with minimal glomerular hyper cellularity. Immunofluorescence showed faint stain for C3 which was similar to biopsy in 1995 suggesting that the disease was in resolving phase at the time of first biopsy and has continued to resolve in last 2 decades. She has Dense deposit disease DDD and has been stable without any nephrotic range proteinuria. She is currently being evaluated for CFHR5 nephropathy gene mutation.

Table 2. Serum protein electrophoresis

\begin{tabular}{ll}
\hline Serum protein & electrophoresis \\
\hline Protein, Total, Serum & $6.8 \mathrm{~g} / \mathrm{dl}(6.0-8.5)$ \\
Albumin & $3.8 \mathrm{~g} / \mathrm{dl}(3.2-5.6)$ \\
Alpha-1-Globulin & $0.2 \mathrm{~g} / \mathrm{dl}(0.1-0.4)$ \\
Alpha-2-Globulin & $0.6 \mathrm{~g} / \mathrm{dl}(0.4-1.2)$ \\
Beta Globulin & $1.0 \mathrm{~g} / \mathrm{dl}(0.6-1.3)$ \\
Gamma Globulin & $1.1 \mathrm{~g} / \mathrm{dl}(0.5-1.6)$ \\
M-Spike & Not Observed \\
Globulin, Total & $3.0 \mathrm{~g} / \mathrm{dl}(2.0-4.5)$ \\
A/G Ratio & $1.3(0.7-2.0)$ \\
\hline
\end{tabular}




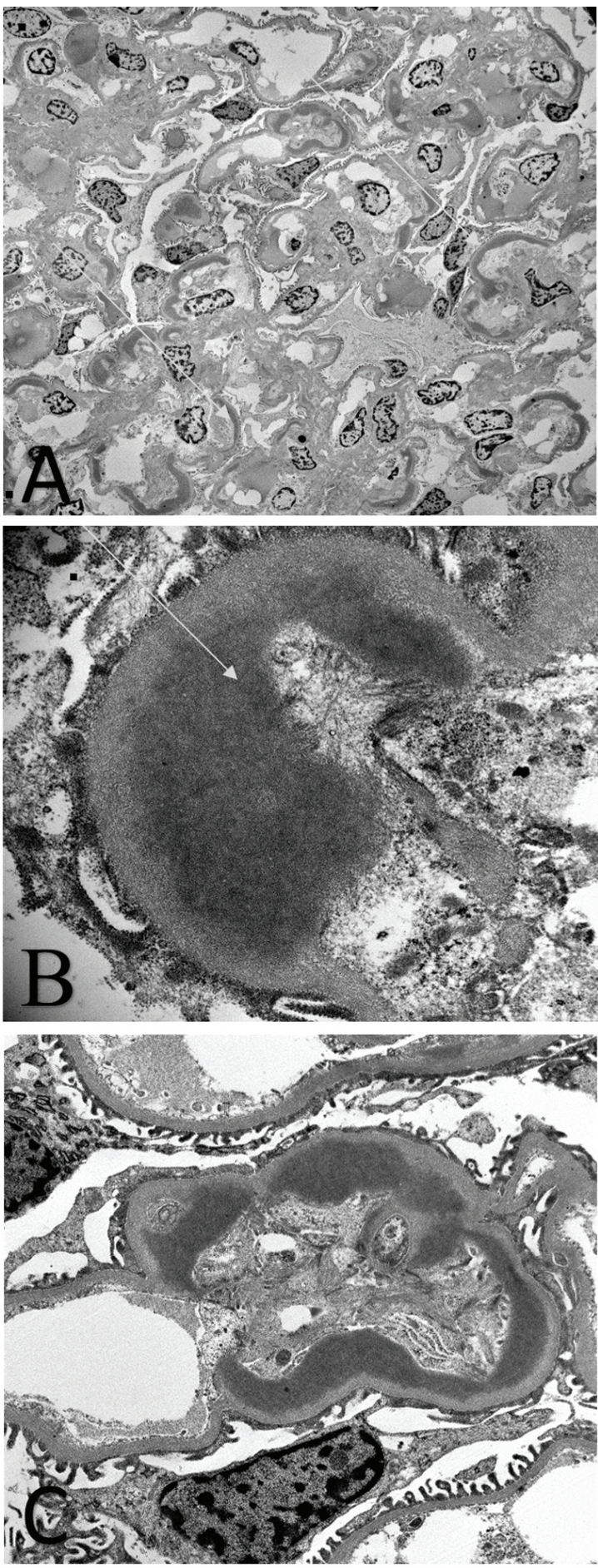

Figure 1. Electron microscopy of this patient showing interrupted band pattern ribbon like electron dense material (arrows) in glomerular basement membranes (A). Electron dense osmiophilic deposit (arrow) in lamina densa of GBM (B). Electron dense material extending into capillary loop with basement membrane on either side (arrow)producing a tram-track appearance (C). Epithelial cell foot processes showing patchy effacement (arrow) in association with deposits (C). Magnification: $\times 1,480$ in A, $\times 25,200$ in B, $\times 9,040$ in $\mathrm{C}$.

\section{Discussion}

C3 glomerulopathy includes both DDD and C3 Glomerulonephritis (C3GN) which are rare forms of Glomerulonephritis affecting both children and adults. They are known to result from abnormal regulation of Alternative Complement pathway. The rarity of this condition presents a challenge for the treating physician and nephrologist.

The term "dense deposit disease" reflects the characteristic appearance of linear hyperosmiophilic electron-dense deposits in the middle layer (lamina densa) of glomerular basement membrane $(\mathrm{GBM})^{[3]}$ (see Figure 1). Similar deposits may occur in mesangium bowman's capsule and tubular basement membrane (see Figure 1). Light microscopy findings are not specific and can include mesangial proliferative, membrano proliferative, endocapillary proliferative glomerulonephritis and crescentic glomerulonephritis. ${ }^{[10]}$ Immunofluorescence microscopy shows $\mathrm{C} 3$ deposits in glomerular, tubular, and Bowman's capsule basement membranes, as well as mesangial rings. Immunoglobulin is typically absent or present at a lower intensity than $\mathrm{C} 3{ }^{[3]} \mathrm{C} 3 \mathrm{GN}$ is diagnosed when the deposits do not fulfill the criteria for DDD.

Excessive activation of alternate complement pathway is the cause of both DDD and C3GN. It is thought to be due to increased activity of $\mathrm{C} 3$ convertase by $\mathrm{C} 3$ nephritic factor $(\mathrm{C} 3 \mathrm{NeF})$ a autoantibody stabilizing $\mathrm{C} 3$ convertase $^{[4,5]}$ or loss of functional factor $\mathrm{H}$ activity. ${ }^{[2,8]} \mathrm{C} 3 \mathrm{NeF}$ has been found to be more common in DDD than C3GN or MPGN type 3. Some studies have also described antibodies to native factor B ( $\mathrm{Cfb})$ which stabilize the AP C3 convertase in DDD. Genetic basis has been associated with DDD in some cases. These include homozygous Cfh deficiency, homozygous loss of function $\mathrm{Cfh}$ mutation, heterozygous gain of function C3 mutation and CFHR mutations leading to enhanced $\mathrm{Cfh}$ deregulation. ${ }^{[10]}$

DDD is diagnosed at a young age compared to $\mathrm{C} 3 \mathrm{GN}$ as documented in various studies. ${ }^{[10]}$ The spectrum of clinical features include nephrotic syndrome, sub nephrotic range proteinuria, macroscopic or microscopic hematuria and acute nephritic syndrome. Persistent microscopic hematuria and episodic synpharyngitic macroscopic hematuria have also been described in DDD patients. ${ }^{[12]}$ Non renal manifestations of DDD include ocular drusen, acquired partial lipodystrophy (PLD), Type $1 \mathrm{DM}$ and Monoclonal gammopathy of undetermined significance (MGUS). ${ }^{[10]}$

Diagnosis of DDD is established by electron microscopy showing characteristic dense deposits in GBM. Consensus report suggests to check complement levels $\mathrm{C} 3$ and $\mathrm{C} 4$, $\mathrm{C} 3 \mathrm{NeF}$, serum factor $\mathrm{H}$ activity, serum protein electrophoresis. ${ }^{[3]}$ Screening for CFHR5 nephropathy disease associated 
mutation should be done. ${ }^{[3]}$ Various observational studies show that more than $50 \%$ of patients with DDD of 10 or more years to progress to ESRD. Treatment options are very few and include antiproteinuric therapy with Reninangiotensin-aldosterone system blockade (RAAS), Immunosuppression with steroids, plasma exchange/infusion. ${ }^{[3]}$ In a recent French $\mathrm{C} 3$ glomerulopathy cohort renal survival was increased by RAAS. ${ }^{[11]}$ In a randomized control trial of 70 children with MPGN steroids showed clinical benefit, of whom 14 had DDD. ${ }^{[13]}$ DDD patients with identified genetic defects in Factor $\mathrm{H}$ benefit from periodic fresh frozen plasma infusions which would replace the missing or mutant protein. ${ }^{[2]}$ Recently a prospective uncontrolled trial reported mixed success with Complement C5 inhibitor Eculizumab. Consensus report suggests a trial of Eculizumab in patients with $\mathrm{C} 3$ glomerulopathy with evidence of $\mathrm{C} 5$ activation either serologically or on kidney biopsy. ${ }^{[3]}$ Transplantation is an option for patients with DDD and C3GN, but the disease tends to recur more frequently than other types of membranoproliferative glomerulonephritis (MPGN), mostly because of a much higher frequency of crescentic disease in DDD. Graft survival is only 50\% in DDD patients with renal transplantation due to disease recurrence. ${ }^{[14]}$

Prognosis of DDD is supposed to be worse than C3GN but the data is from old trials. Schwertz et al. 1996 reported the ESRD rate of $70 \%$ in individuals diagnosed with DDD after the median period of 9 years from diagnosis. ${ }^{[5,7]}$ ESRD progression is reported to be $50 \%$ within 10 years from diagnosis in patients with DDD who are younger than 10 years at diagnosis. ${ }^{[14]}$ Our patient demonstrated significant resolution of glomerular hyper cellularity and dense deposits in electron microscopy over the last 2 decades (see Figures 2, 3) which is an unusual clinical course in DDD. Our patient is very unique given the duration of 20 years of stable dense deposit disease. Further research is needed to correlate the morphological changes in biopsy with clinical course and outcomes.

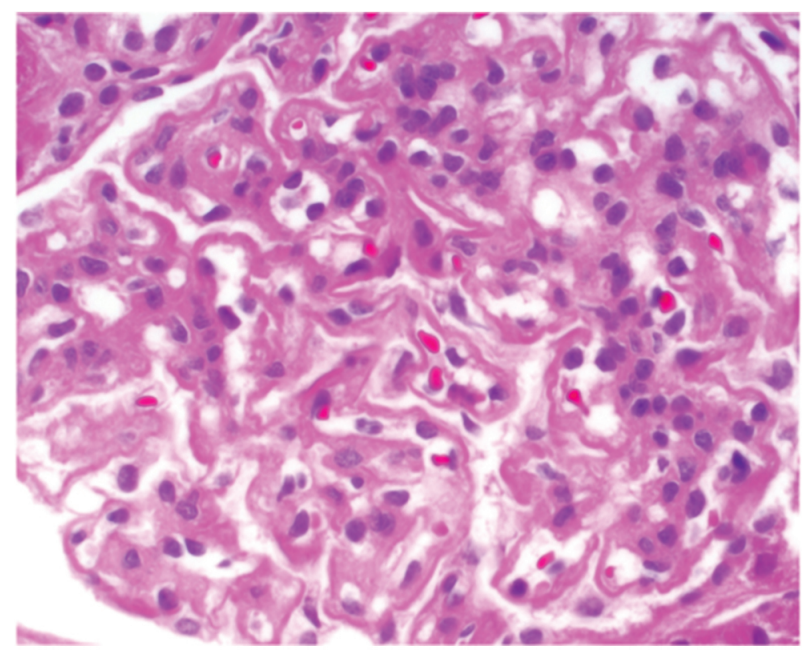

Figure 2. Renal Biopsy from 1995. Light microscopy showing areas of glomerular hyper cellularity

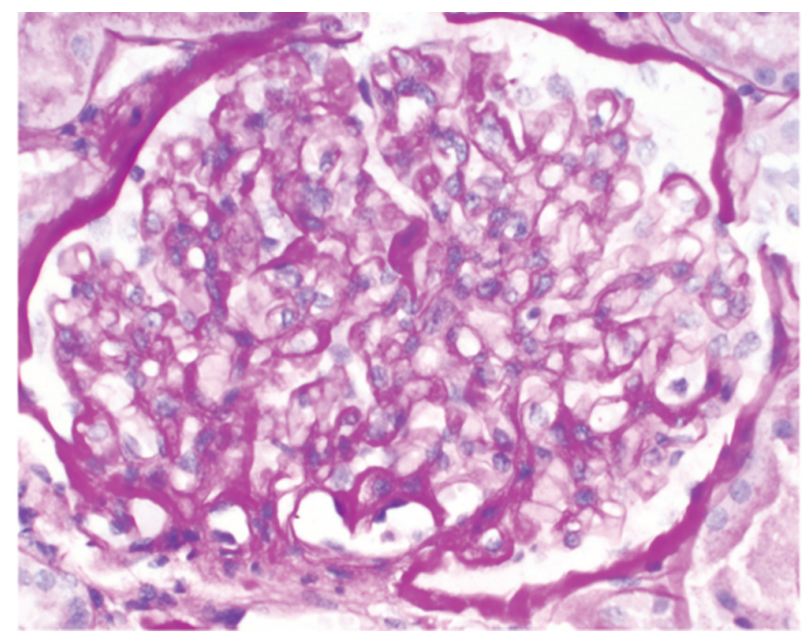

Figure 3. Renal Biopsy from 2016. Light microscopy showing minimal glomerular hyper cellularity

\section{CONFLicts OF InTERest Disclosure}

The authors have declared no conflicts of interest.

\section{REFERENCES}

[1] Appel GB, Cook HT, Hageman G, et al. Membranoproliferative glomerulonephritis type II (dense deposit disease): an update Journal of American Society of Nephrology. 2006; 16(5): 13921403. PMid:16612335 http://dx.doi.org/10.1038/sj.ki.5 000269

[2] Licht C, Heinen S, Józsi M, et al. Deletion of Lys224 in regulatory domain 4 of Factor $\mathrm{H}$ reveals a novel pathomechanism for dense deposit disease (MPGN II). Kidney Int. 2006; 70(1): 42-50.

[3] Pickering MC, D'Agati VD, Nester CM, et al. C3 Glomerulopathy: Consensus Report. Kidney International. 2013; 84(6): 1079-1089.
PMid:24172683 http://dx.doi.org/10.1038/ki.2013.377

[4] Schwertz R, Rother U, Anders D, et al. Complement analysis in children with idiopathic membranoproliferative glomerulonephritis: a long-term follow-up. Pediatr Allergy Immunol. 2011; 12(3): 16672. http://dx.doi.org/10.1034/j.1399-3038.2001.01200 $3166 \cdot \mathrm{x}$

[5] Schwertz R, de Jong R, Gretz N, et al. Outcome of idiopathic membranoproliferative glomerulonephritis in children. Arbeitsgemeinschaft Pädiatrische Nephrologie. Acta Paediatr. 1996; 85(3): 30812. PMid:8695987 http://dx.doi.org/10.1111/j.1651-222 7.1996.tb14022.x 
[6] Sethi S, Fervenza FC, Zhang Y, et al. C3 Glomerulonephritis: clinicopathological findings, complement abnormalities, glomerular proteomic profile, treatment, and follow up. Kidney Int. 2012; 82(4): 465-73. PMid:22673887

[7] Smith RJH, Harris CL, Pickering MC. Dense deposit disease. Molecular Immunology. 2011; 48(14): 1604-10. PMid:21601923 http: //dx.doi.org/10.1016/j.molimm.2011.04.005

[8] Smith RJH, Alexander J, Barlow PN, et al. New approaches to the treatment of dense deposit disease. J Am Soc Nephrol. 2007; 18(9): 2447-56. PMid:17675665 http://dx.doi.org/10.1681/ASN . 2 007030356

[9] Swainson CP, Robson JS, Thomson D, et al. Mesangiocapillary glomerulonephritis: a long-term study of 40 cases. J Pathol. 1983; 141(4): 449-468. PMid:6363655 http://dx.doi.org/10.1002 /path.1711410404

[10] Barbour TD, Pickering MC, Cook HT. Dense deposit disease and C3 Glomerulopathy. Seminar in Nephrology. 2013; 33(6): 493-507. PMid:24161036 http://dx.doi.org/10.1016/j . semnephrol. 2013.08 .002
[11] Servais A, Noel LH, Roumenina LT, et al. Acquired and genetic complement abnormalities play a critical role in dense deposit disease and other C3 glomerulopathies. Kidney Int. 2012; 82(4): 454-64. PMid:22456601 http://dx.doi.org/10.1038/ki.2012.63

[12] Bennett WM, Fassett RG, Walker RG, et al. Mesangiocapillary glomerulonephritis type II (dense-deposit disease): clinical features of progressive disease. Am J Kidney Dis. 1989; 13(6): 469-476. http://dx.doi.org/10.1016/S0272-6386(89)80004-6

[13] Tarshish P, Bernstein J, Tobin JN, et al. Treatment of mesangiocapillary glomerulonephritis with alternate-day prednisone-a report of the International Study of Kidney Disease in Children. Pediatr Nephrol. 1992; 6(2): 123-130. PMid:1571205 http://dx .doi .org/10.10 $07 / \mathrm{BF} 00866289$

[14] Smith RJH, Alexander J, Barlow PN, et al. New approaches to the treatment of Dense deposit disease. J Am Soc Nephrol. 2007; 18(9): 2447-2456. PMid:17675665 http://dx.doi.org/10.1681/ASN .2007030356 